Portland State University

PDXScholar

1971

\title{
Lactic dehydrogenase isozyme isolation by disc electrophoresis in eight species of fringillid birds
}

Michael Edwin Darling

Portland State University

Follow this and additional works at: https://pdxscholar.library.pdx.edu/open_access_etds

Part of the Biochemistry, Biophysics, and Structural Biology Commons, Organismal Biological Physiology Commons, and the Ornithology Commons Let us know how access to this document benefits you.

\section{Recommended Citation}

Darling, Michael Edwin, "Lactic dehydrogenase isozyme isolation by disc electrophoresis in eight species of fringillid birds" (1971). Dissertations and Theses. Paper 1452.

https://doi.org/10.15760/etd.1451

This Thesis is brought to you for free and open access. It has been accepted for inclusion in Dissertations and Theses by an authorized administrator of PDXScholar. Please contact us if we can make this document more accessible: pdxscholar@pdx.edu. 
AN ABSTRACT OF THE THESIS OF Michael E. Darling for the Master of Sclence In Blology presented July 29, 1971.

Title: Lactic Dehydrogenase Isozyme Isolation by Dlsc Electrophoresis In Eight Species of Fringillid Birds. APPROVED BY MEMBERS OF THE THESIS COMMITTEE:

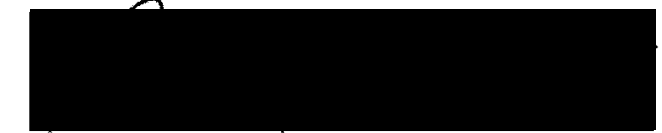

Richard B. Forbes, Chairman

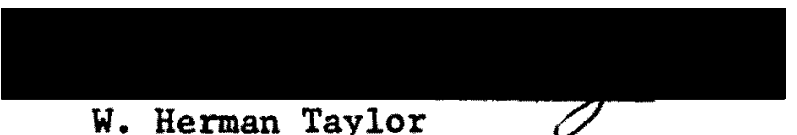

W. Herman Taylor

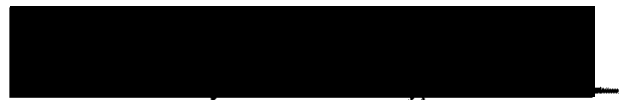
Mary L./Taylor 0

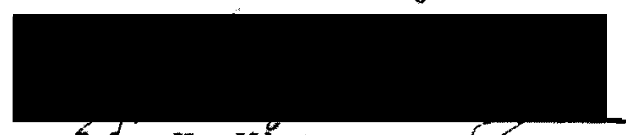

John H. Wirtz

Disc electrophoresis of tissue homogenates from eight species of fringillid birds showed flve forms of lactic dehydrogenase. The relative amounts of isozymes were characteristic for each spectes. This paper classifies some members of the families Fringillidae and Carduelidae in terms of lactic dehydrogenase isozymes and compares the results to other methods of classification. 
LACTIC DEHYDROGENASE ISOZYAR ISOLATION BY DISC ELECTROPHORESIS IN

EIGHT SPECIEN OF FIRINGILLID BIRDS

$B Y$

Michael Edwin Darling

A thesis submitted in partial fulfillment of the requirements for the degree of

NASTER OF SCTENCE

IN

BIOLOGY

Portland State University

1971 
TO THE OFFICE OF GRADUATE STUDIES:

The members of the Committee approve the thesis of

Michael E. Darling presented July 29,1970.
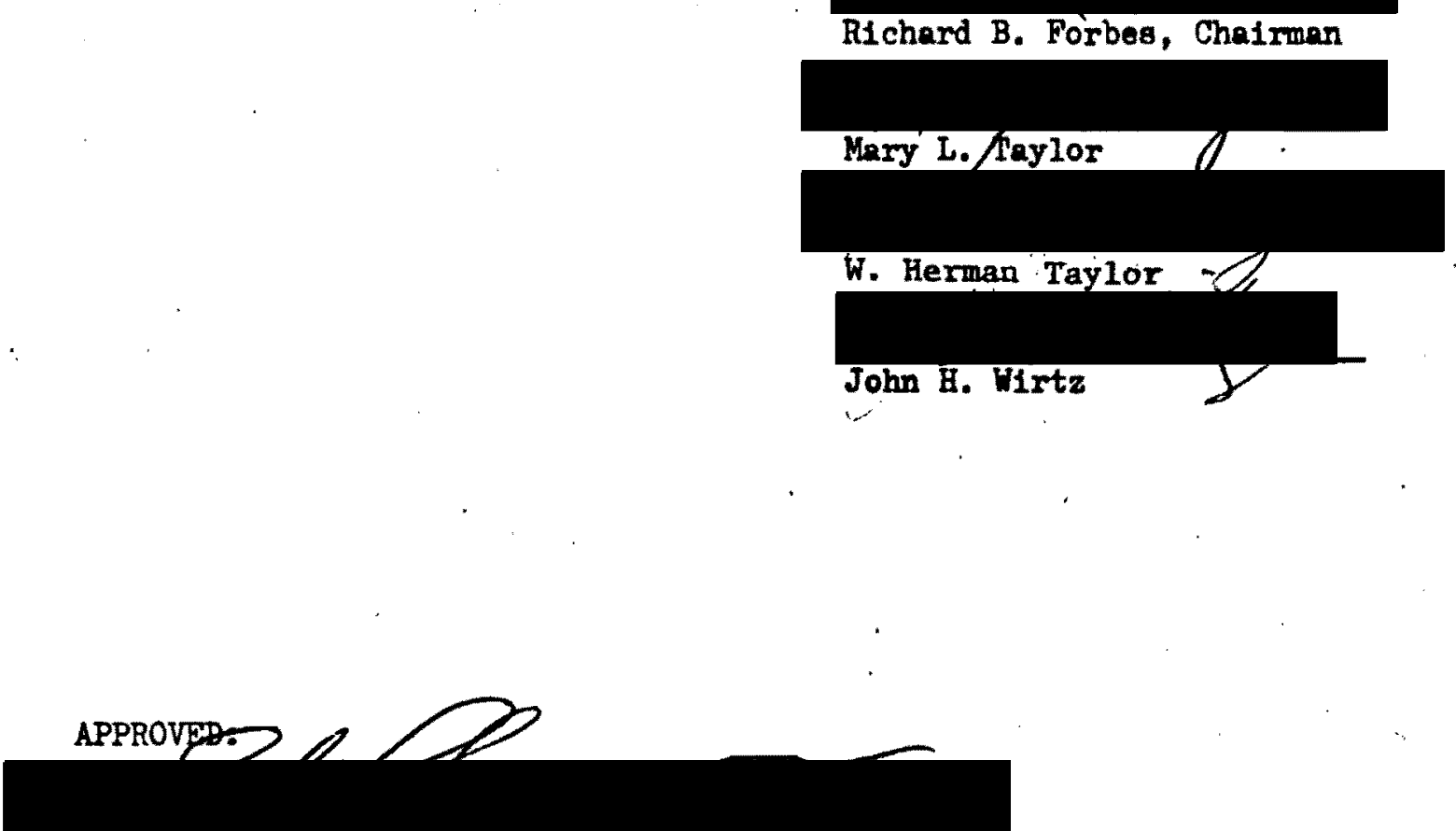

Earl Fjokex, JR., Head, Department of Blolegy

David T. Clark, Dean of Graduate Studies

July 29, 1970 
ACKNOWLEDGEMTST $\ldots \ldots \ldots \ldots \ldots \ldots \ldots \ldots \ldots \ldots \ldots \ldots \ldots \ldots \ldots \ldots \ldots \ldots$

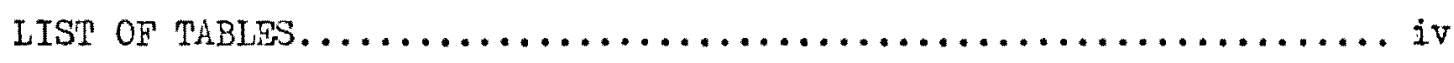

LIST OF FTGURES $\ldots \ldots \ldots \ldots \ldots \ldots \ldots \ldots \ldots \ldots \ldots \ldots \ldots \ldots \ldots \ldots \ldots \ldots$ v

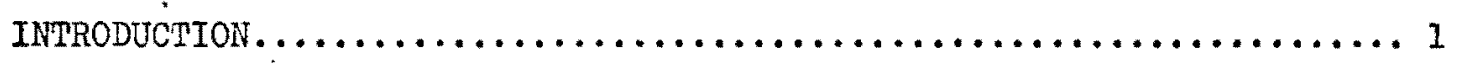

MATERIALS AND METHODS

Collecting fringillid birds..................... 4

Methods for lactic dehydrogenase study................ 6

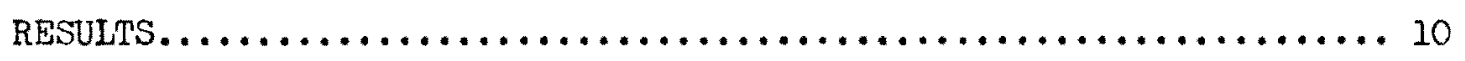

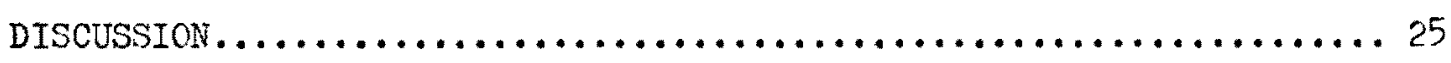

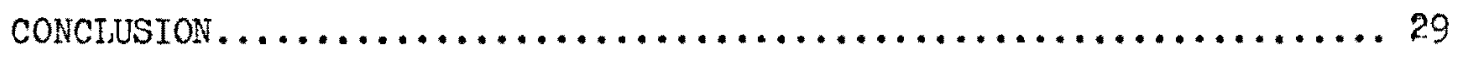

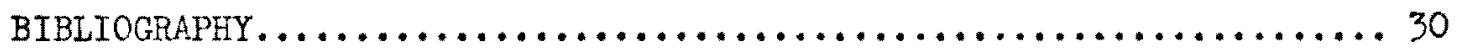


I am indebted for assistance with the laboratory work to Mary L. Tayior. The Portiand State University Biology department has supported this work by providing facilities and equipment. For advice and other assistance I am grateful to Richard B. Forbes, Earl Fisher Jr., John Wirtz, Donald Eames, and Richard Avedovech. 
PAGE

Table I: Capture data for eight species of fringillid birds

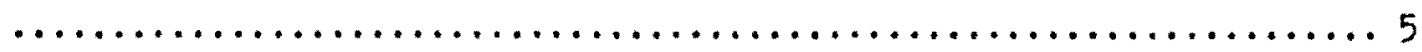

Tablo II. Five classification schemes for eight species of fringillid birds $\ldots \ldots \ldots \ldots \ldots \ldots \ldots \ldots \ldots \ldots \ldots \ldots \ldots \ldots \ldots \ldots$ 
LIST OF FIGURES

PAGE

Figure 1. Protein determination for unknown samples of fringillid

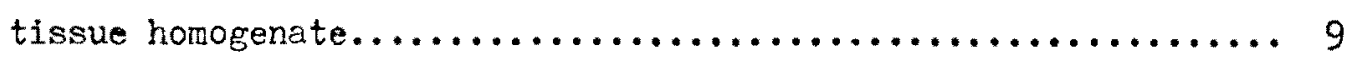

Figure 2. Lactic dehydrogenase isozyme migration after 30 minutes

past tracer in a female house finch................... 12 .

Figure 3. Lactic dehydrogenase isozyme migration after 75 minutes

past tracer in a female house finch................. 13

Figure 4. Lactic dehydrogenase isozyme migration after 120 minutes

past tracer in a female house finch.................. 14

Figure 5. Lactic dehydrogenase isozyme pattern in a male black-

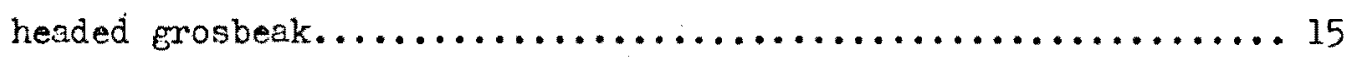

Figure 6. Lactic dehydrogenase isozyme pattern in a male evening

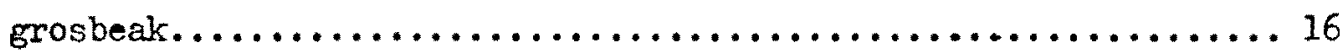

Figure 7. Lactic dehydrogenase isozyme pattern in a male Oregon

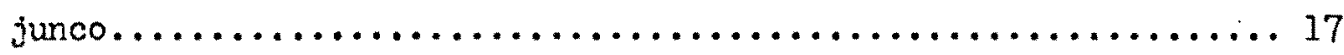

Fj.gure 8. Lactic dehydrogenase isozyme pattern in a male rufous-

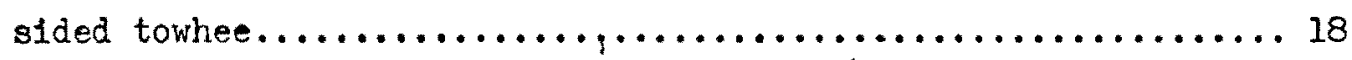

Figure 9. Lactic dehydrogenase isozyme pattern in a male white-

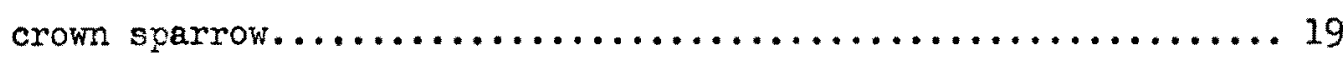

Figure 10. Lactic dehydrogenase isozyme pattern in a male house

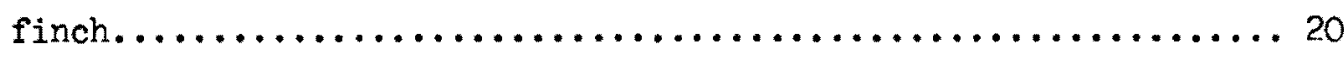

Figure 11. Lactic dehydrogenase isozyme pattern in a male song

sparrow....................................... 21 
LIST OF FIGURES CONT.

PAGE

Figure 12. Iactic dehydrogenase isozyme pattern in a male fox

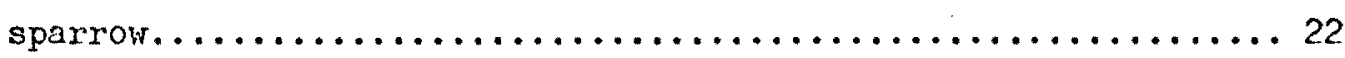

Figure 13. Lactic dehydrogenase isozyme pattern shown in gel tracings using rufous-sided towhee and fox and song sparrows......... 23

Figure 14. Summary of data from the taxonomy of eight species of

fringillid birds...................................... 24 
Birds and mamals have five multiple molecular forms of lactic dehydrogenase (IDH). The multiple molecular forms found in a given species are called isozymes. Each isozyme can be separated into four subunits of the same molecular veight. The four subunits can be separated into two classes of polypeptide chains, $H$ and $M$. The isozyme designated $M_{4}$ consists of four $M$ chains. The isozyme designated $\mathrm{H}_{1} \mathrm{M}_{3}$ consists of three $\mathrm{H}$ chains and one $\mathrm{H}$ chain. The isozyme designated $\mathrm{H}_{2} \mathrm{H}_{2}$ consists of two $M$ chains and two $H$ chains. The isozyme designated $\mathrm{H}_{3} \mathrm{M}_{1}$ consists of one $\mathrm{M}$ chain and three $\mathrm{H}$ chains. The isozyme designated $\mathrm{H}_{4}$ consists of four $\mathrm{H}$ chains (Lehninger, 1970). All isozymes have the same molecular weight and carry out the same overall reactions, but differ in chemical structure, immunological properties, shape, and charge. The $\mathrm{H}_{4}$ isozyme is found to predominate in the heert muscle and is strongly inhibited by a high pyruvate concentration. Ratite birds and poor fliers have the $M$ type in their breast muscles, whereas stronger fliers have a much larger percentage of the H type (Fine and Costello, 1962). Pymuvate in fatty acid metabolism is converted into lactate. $\mathrm{H}_{4}$ isozyme may be necessary in the control of this pathway (Fine and Costello, 1962). The $\mathrm{M}_{4}$ isozyme predominates in the white skeletal muscle and is weakly inhibited by high pryuvate concentrations (Bailey and Wilson, 1968).

All the cells of an animal have the capacity to produce 
combinations of both types of LDH, but there are unknown mechanisms involved in its differentiation and development. Each organ possesses a different quantitative amount of each type (Fine and Costello, 1962). According to the subunit hypothesis, LDH isozymes are composed of two subunits, $A$ and $B$ in varying combinations of four. According to Vesell and Brody (1964), each subunit is under the control of two separate genes, $a$ and $b$. The differences in the relative activity of these genes from one tissue to another and the randon recombination of the subunits produced by the genes provides the explanation of the variation in isozyme pattern in specialized cells of the same organism.

The homologies of $\mathrm{LDH}$ among classes of chordates are complex; however, a taxonomic study of LDH isozymes homologies may lead to a greater understanding of genetic relationships between groups of organisms. The evolution of proteins such as $\mathrm{LDH}$ provides an advantage over morphological characteristics in taxonomic studies in that these molecules may be less subject to gradual genetic change. However, morphology and behavior are linked to biochemistry. An incorporation of morohological, physiological, and biochemical methods gives the clearest and most accurate picture of taxonomy (Defalco, 1942).

The objective of this study was to compare the amount and pattern of LDH isozyme in eight species of fringillid birds. A disc electrophoresis unit was used for the separation of proteins due to their difference in charge. It has the adventage, as 
opposed to starch block electrorhoresis used by Fine and Costello (1962) and Bailey and Wilson (1968) of high resolution in brief runs. Only small quantities of protein are required, due to the fact that dilute protein samples are concentrated into discs of ten microns thickness at the beginning of the run before separation (Omstein and Davis, 1961). If equal protein concentrations are subjected to electrophoresis under standard muning conditions, a fair comparison of eight species of fringillid birds can be made. 
AlI birds were caught with mist nets set on the East side of Rocky Butte, Multnomah County, Oregon, between 15 July 1970 and 15 August 1970. A $12 \mathrm{ft}$. x $6 \mathrm{ft}$. net was set in an open field surrounded by a Douglas fir and mixed deciduous forest. A second $8 \mathrm{ft}$. $\times 31 / 2 \mathrm{ft}$. net of smaller mesh was set as a backup net approximately $8 \mathrm{ft}$. behind the first. The second net could catch smaller birds, and if the birds avoided the first net they might become entangled in the second. The method was essentially the same as that of Johns (1963). As suggested by lartin (1969), care was taken not to trample feeding and netting areas in the field. The birds were captured then berries and other fruits were abundant. Traps utilizing food as a bait were useless during this time. Care was taken not to over-chloroform captured birds in order to avoid liver damage. The dead birds were weighed and frozen. Lccation of capture recorded. Capture data is summarized in Table I. 
TABJE I. Capture data for eight species of fringillid birds.

5

All birds were collected on the East side of Rocky Butte, Portland Oregon.

Date of Capture: Scientific names: Common name and sex:

$7 / 15 / 70$

$7 / 21 / 70$

$8 / 1 / 70$

$8 / 1 / 70$

$8 / 7 / 70$

$8 / 8 / 70$

$8 / 11 / 70$

$8 / 15 / 70$
Melospiza melodia

Carpodacus mexicans

Passerella iliaca

Junco oreganus

Pipilo erythrophthalmus

Pheucticus melanocephalus male black-headed

Hesperiohona vespertina male evening

Zonotrichia leucophrys grosbeak

grosbeak

male song sparrow

male house finch

male fox sparrow

male Oregon junco

male rufous-sided

towhee

male white-crown

sparrow 
Chemicals purchased from Sigma Chemical are as follows; glycine, phenazene methosulfate, diphosphopyridine nucleotide, and potassium ferricyanide. Chemicals purchased from Mallinckrodt are as follows; potassium tartrate, copper sulfate, and sodium hydroxide. Chemicals purchased from Baker Chemical are as follows; glacial acetic acid and $\mathrm{N}, \mathrm{N}^{\prime}$ methylenebisacrylamide. Watheson Coleman and Bell chemicals were purchased as follows; 2-amino-2 (Hydroxymethyl)-1,3propanediol (Tris), emmoniun persulfate, ammonium sulfate, hydrochloric acid, acrylamide, bromphenol blue, trichloroacetic acid, riboflavin, $N, N, N^{\prime}, N^{\prime}$ tetramethylethylenediamine. Folin resgent was purchased from Uni-Teck. A Buchler electrophoresis polyanalyst unit was used with a current-regulated power supply.

Birds were thawed and liver, heart, and breast muscle were removed and minced separately. Equal volumes of each tissue were added to five volumes of $0.25 \mathrm{M}$ sucrose and placed in a Sorvall Omnimixer at a setting of 7 for one minute. This mixture was then homogenized in a Potter-Elvehem glass homogenizer and centrifuged at $30,000 \times g$ for 30 minutes at $0 \mathrm{C}$. The supernatant was poured off and frozen at $-20 \mathrm{C}$.

Lactic dehydrogenase was partially purified as follows. Amonium sulfate was added to $40 \%$ saturation $(\mathrm{w} / \mathrm{v})$. The solution was centrifuged at $30,000 \times g$ for 10 minutes and the pellet discarded. Ammonium sulfate was added to the supernatant to give $60 \%$ saturation (w/v). 
The solution was allowed to equilibrate for 15 minutes and centrifuged at $30,000 \times \mathrm{g}$ for 10 minutes. The $60 \%$ ammonium sulfate pellet was suspended in two pellet-volumes of the $60 \%$ ammonium sulfate supernatant. This solution was dialyz $\geq$ against 500 volumes of $5 \mathrm{mM}$ Tris-HCL buffer $(\mathrm{pH} 8.5)$ for 24 hours at $6.6 \mathrm{c}$.

Protein concentration was determined by the method given by Lowry et al. (1951). Using bovine serum albumin as the standard, unknown protein concentrations could be calculated (Figure 1). Each sample was adjusted to $250 \mathrm{ug} / \mathrm{ml}$ of notein prior to electrophoresis. Each electrophoresis run lasted 45 minutes after bromphenol blue tracer reached the end of the gel.

The method of disc electrophoresis was essentially the same as that done by Ornstein and Davis (1961) with the following changes. Protein samples were added to a $40 \%$ sucrose solution. Each sample was added with a long pipet directly to the top of the stacking gel. The whole unit was run at $6.6 \mathrm{C}$. The upper buffer contained $5.16 \mathrm{~g}$ Tris, $3.48 \mathrm{~g}$ glycine and water to 1 liter. The $\mathrm{pH}$ at 22. $C$ was 8.9 and at $0 \mathrm{C}, 9.64$. The lower buffer contained 14 8 Tris, $60 \mathrm{ml} \mathrm{I} \mathrm{N} \mathrm{HCL} \mathrm{and} 940 \mathrm{ml}$ of water. The $\mathrm{pH}$ of the lower buffer at $22 \mathrm{C}$ was 8.07 and at $\mathrm{O}, 8.84$. Duplicate gels $3 \mathrm{~cm}$ in length were prepared from each protein sample. Protein bands were stained with Coomassie blue according to the procedure of Chrambach et 21. (1967). This procedure permitted comparison of amounts of isozyme in different samples. Protein bands of $\mathrm{LDH}$ were detected by the nitro-blue tetrazolium (NBT) staining method of Fine and 
Costello (1962). This method is extremely sensitive, but the amount of IDH activity cannot be quantified using this procedure. Gel tracjugs were recorded on a Densicord recording electrophoresis densitometer using filter no. 610 and no. 5 response. Comparisons between the tracings of the protein and NBT stains were made by aligning the stacking gels. Lactic dehydrogenase isozymes were labeled and a comparison of sample was made from sets of tracings. Individual variation was found by McCabre (1952) to prevent distinction of species by egg white protein samples. McCabre also found individual variation in serum protein patterns if the birds tested were not healthy, or differed in age and sex. The birds used in this study were males, had underæone their post-juvenal molt, and appeared to be healthy. Under the conditions of this experiment, protein samples of two song sparrows had identical $\mathrm{LDH}$ patterns. 


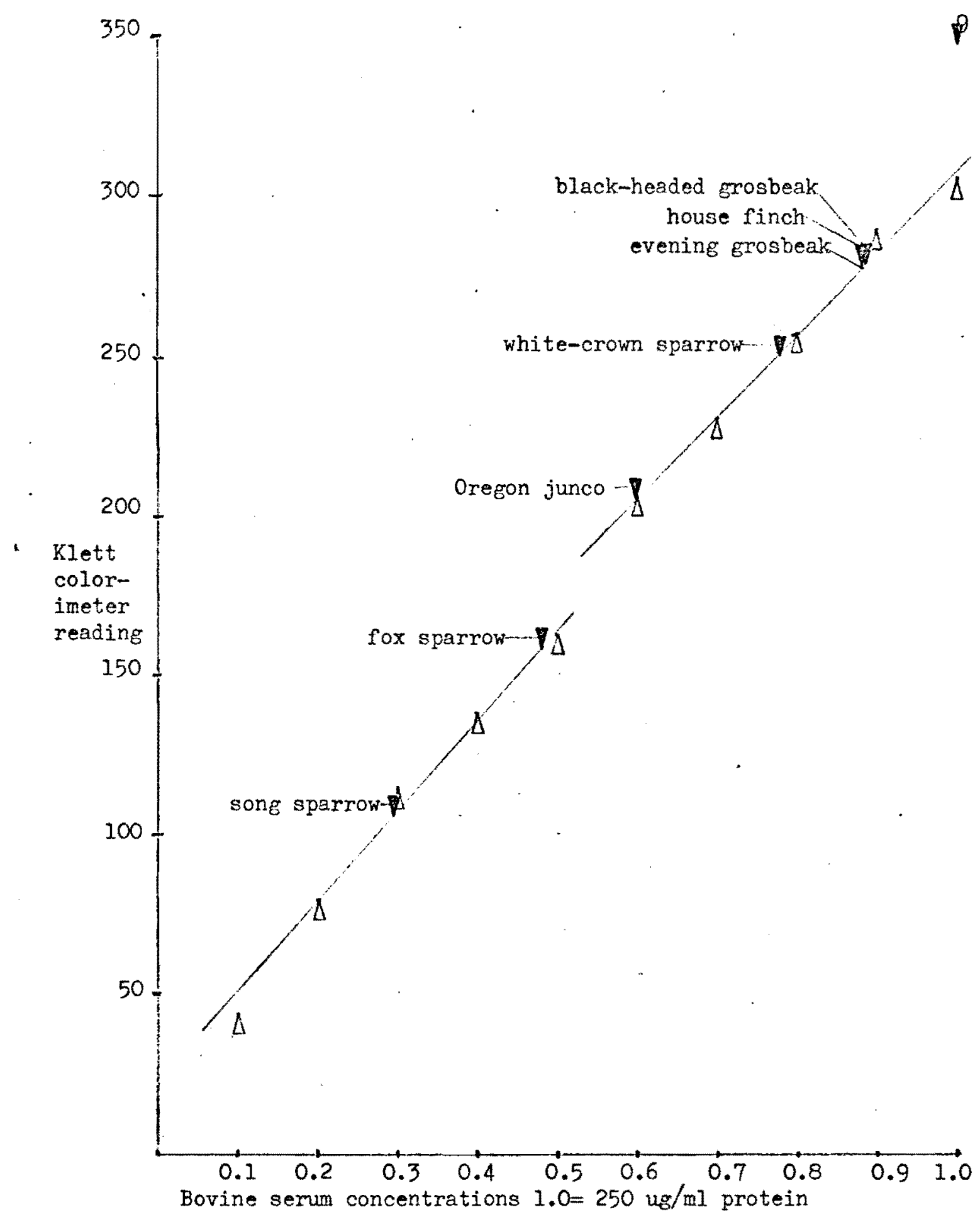

Figure 1. Standard curve for determining protein concentration of samples for electrophoresis; $\Delta=$ bovine serum plots; $=$ bird protein sample. 
Qualitative data are often more useful than quantitative data in biochemical taxonomic studies (Sibley and Johnsgard, 1959).

A female house finch was used in the study of lactic dehydrogenase isozyme migration. Gels were removed from the electrophoresis unit at intervals of 30,75 , and 120 minutes after the tracer reached the bottom of the gel. At 120 minutes splitting occurred in the isozyme patterns. The homogenate had been frozen a number of times to $-20 \mathrm{C}$. The same results were found by Vesell and Brody (1968). Results are shown on Figures 2, 3, and 4.

The $\mathrm{H}_{4}$ isozyme appeared on the NBT stain as a massive broad peak with very little protein detected on the Coomassie blue tetrazolium stain.

The results of the taxonomic experiments on eight species of fringillid birds are show in Figures 5 through 12. The sorg sparrow and the fox sparrow are grouped independently from the rest of the birds studied due to the following characteristics: the five isozymes did not migrate as far; there is higher amounts of $\mathrm{H}_{4}$ isozyme; $\mathrm{H}_{2} \mathrm{M}_{2}$ isozyme was very small or missing; this group lacks the sharp partition between $\mathrm{H}_{2} \mathrm{M}_{2}$ and $\mathrm{H}_{3} \mathrm{M}_{1}$ isozymes.

The black-headed grosbeak and evening grosbeak are loosely grouped togethed due to the large $\mathrm{H}_{3} \mathrm{M}_{1}$ isozyme activity on the NBT stain with very little protein existing. The rufous-sided towhee, whitecrown sparrow, and the Oregon junco are linked with the black-headed grosbeak and the evening grosbeak by having very little $\mathrm{H}_{1} \mathrm{M}_{3}$ isozyme 
with a large amount of NBT activity. Unlike the latter group of

birds, the house finch has a moderate amount of the $\mathrm{H}_{1} \mathrm{M}_{3}$ isozyme.

Representative gels of several species are shown in Figure 13.

Figure 14 summarizes the data from Figures 5 through 12. 


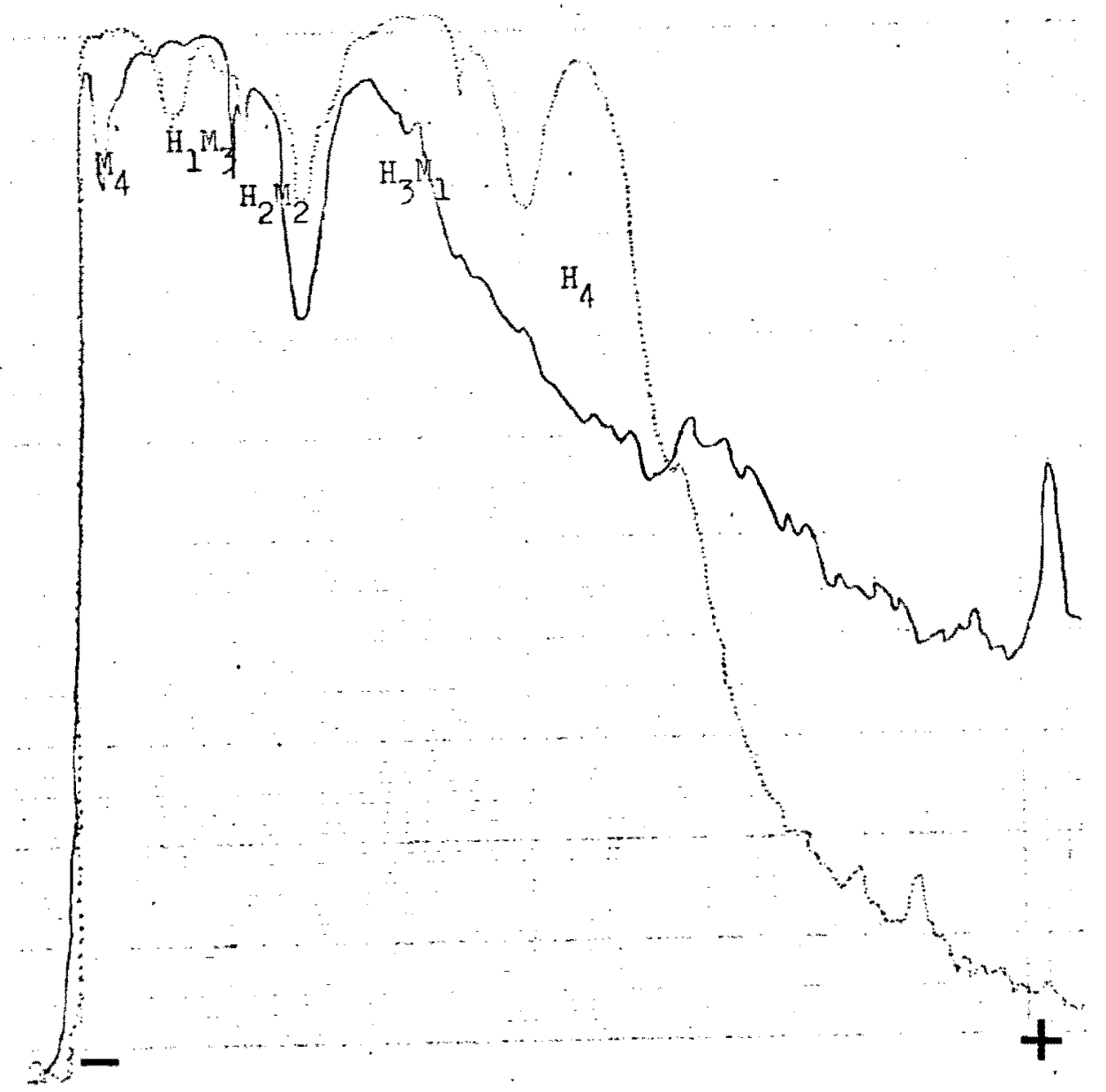

Figure 2. Pattern of LDH isozyme migration after 30 minutes past the tracer. Solid line represents protein stain (Coomassie blue); dotted line represents activity stain (NBT). A female house finch was used as a sample. Migration of the proteins is from left to right. 


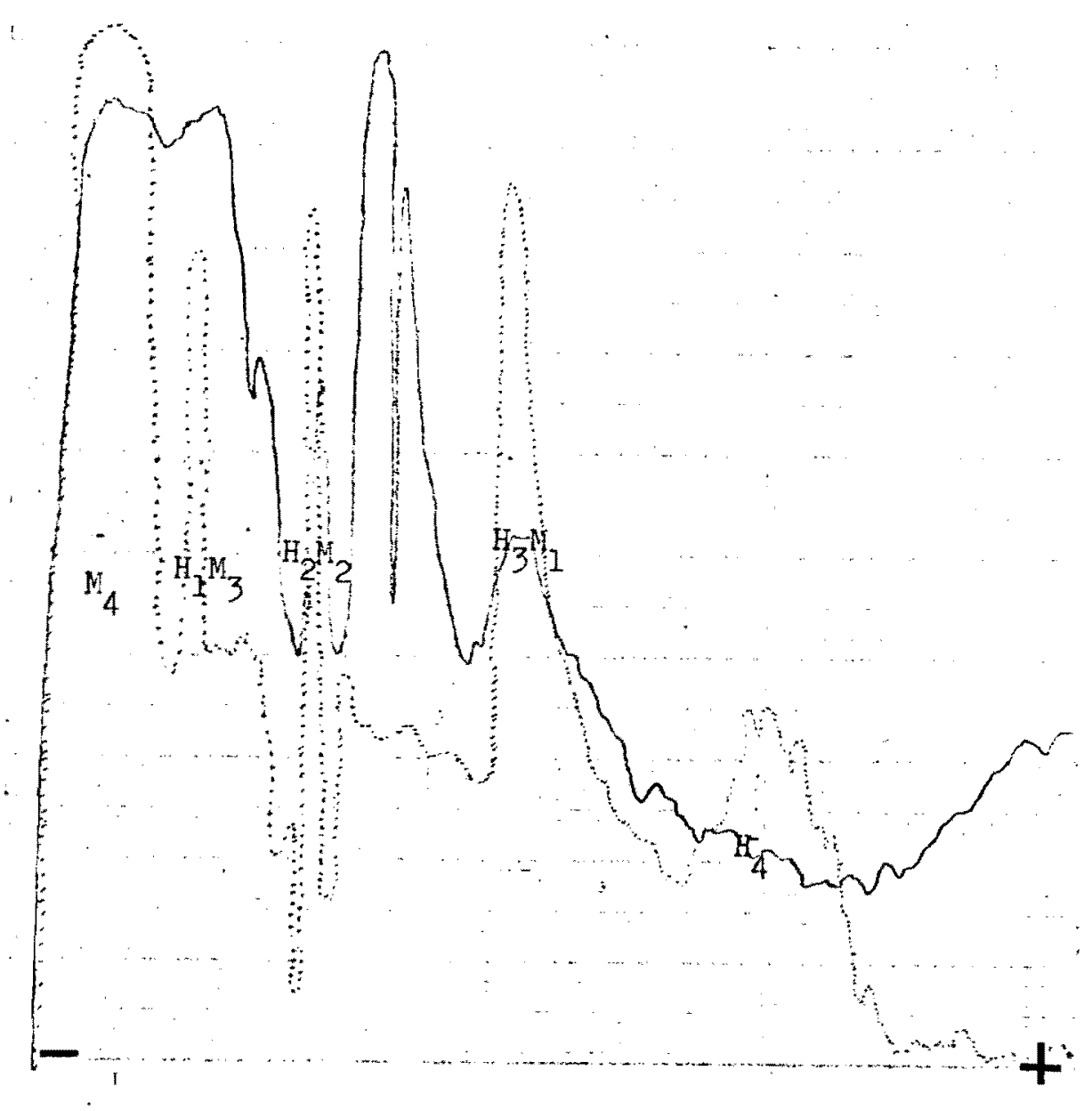

Figure 3. Pattern of $\mathrm{LDH}$ isozyme migration after 75 minutes past the tracer. Solid line represents protein stain (Coomassie blue); dotted line represents activity stain (NBT). A female house finch was used as a sample. Migration of the proteins is from left to right. 


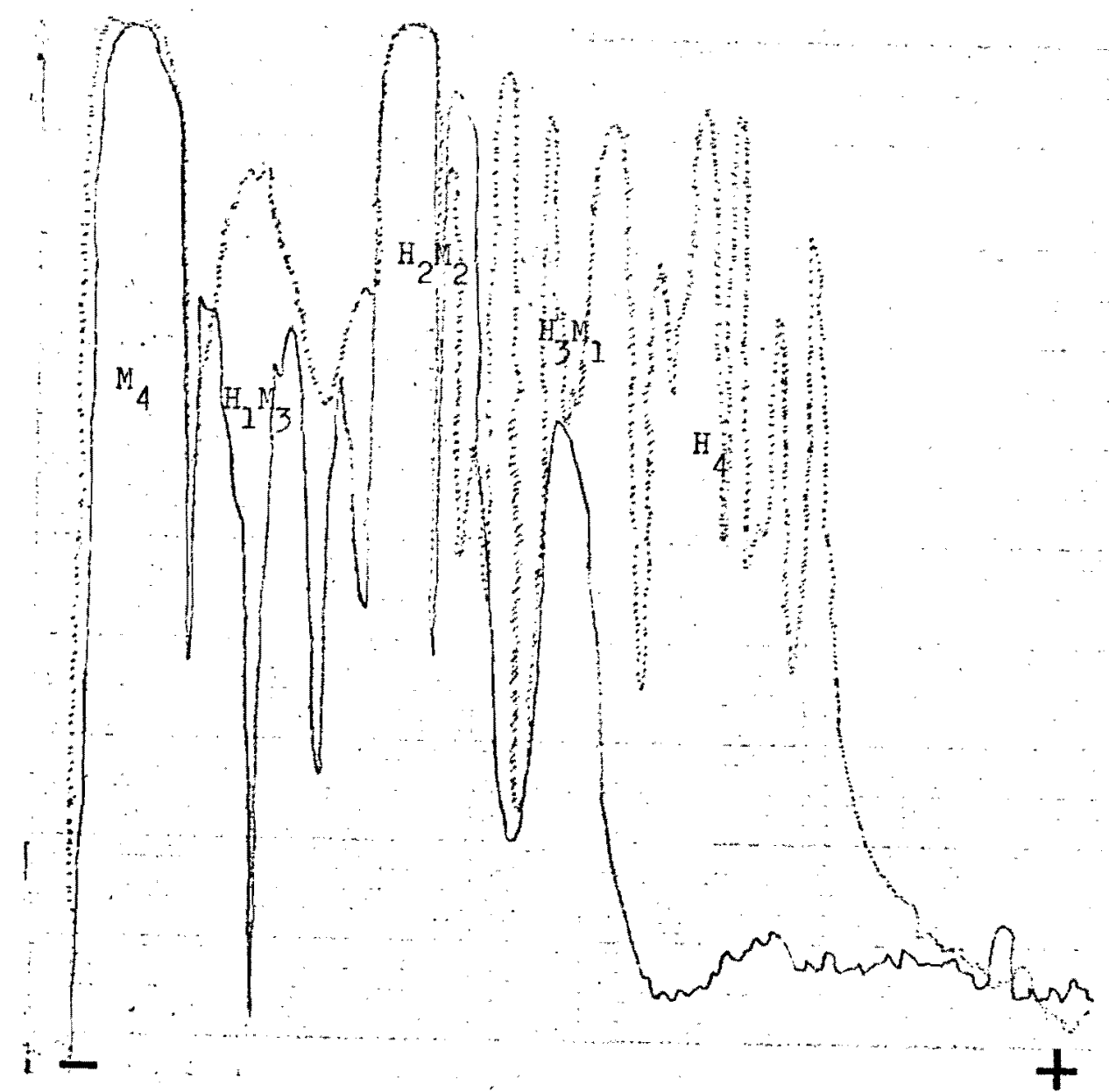

Figure 4. Pattern of $\mathrm{LDH}$ isozyme migration after 120 minutes past the tracer. Solid line represents protein stain (Coomassie blue); dotted line represents activity stain (NBT). A female house finch was used as a sample. Migration of the proteins is from left to right. Note the splitting of $\mathrm{H}_{3} \mathrm{M}_{2}$ and $\mathrm{H}_{4}$ isozymes due to the freezing of the homogenate. 


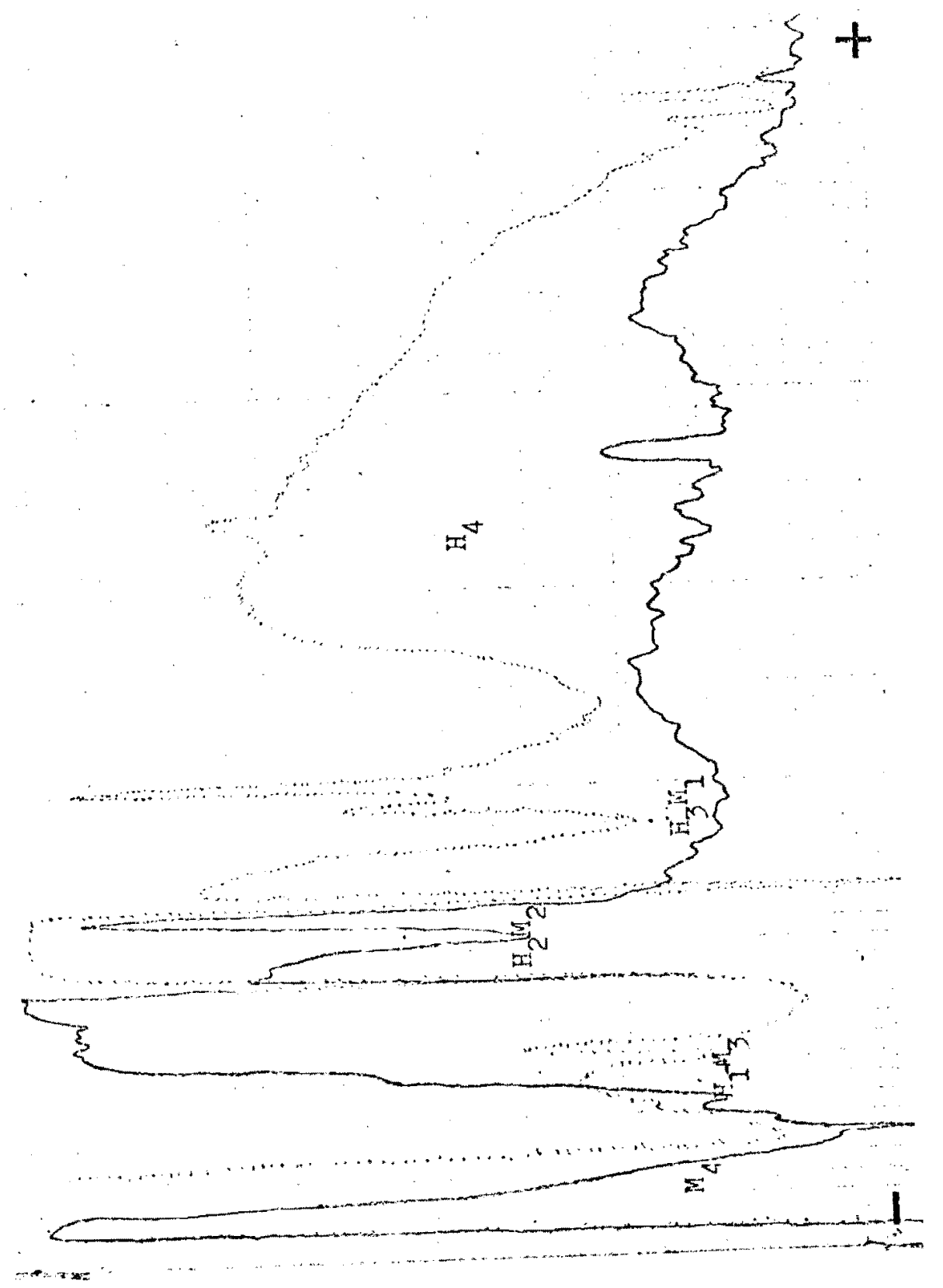

Figure 5. Fattern of LDH isozyme densitometer tracings of a male black-headed grosbeak. Solid line represents protein stain

(Coomassie blue); dotted line represents activity stain (NBT). 


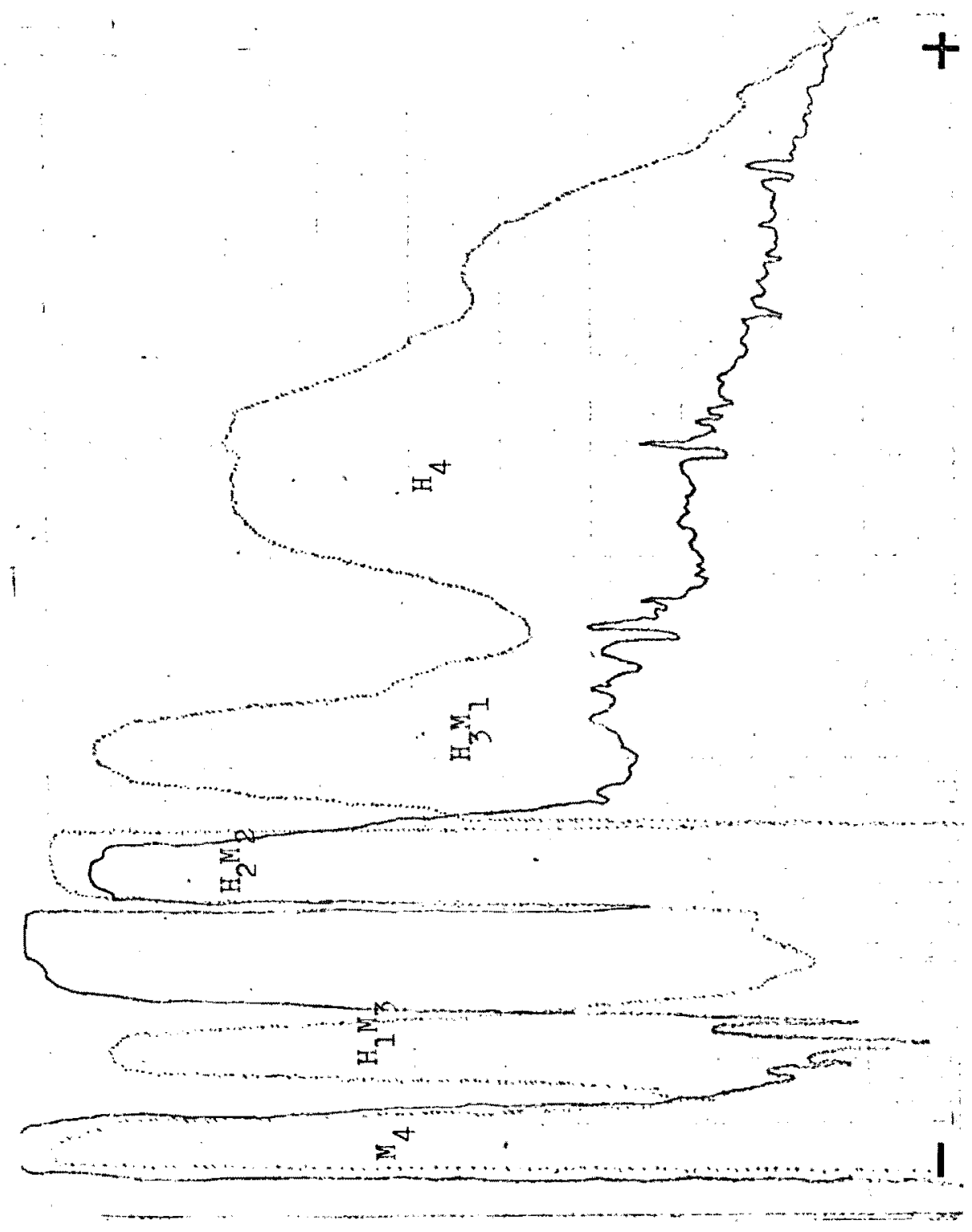

Figure 6. Pattern of $L D H$ isozyme densitometer tracings of a male evening grosbeak. Solid line represents protein stain (Coomessie blue); dotted line represents activity stain (NBT). 


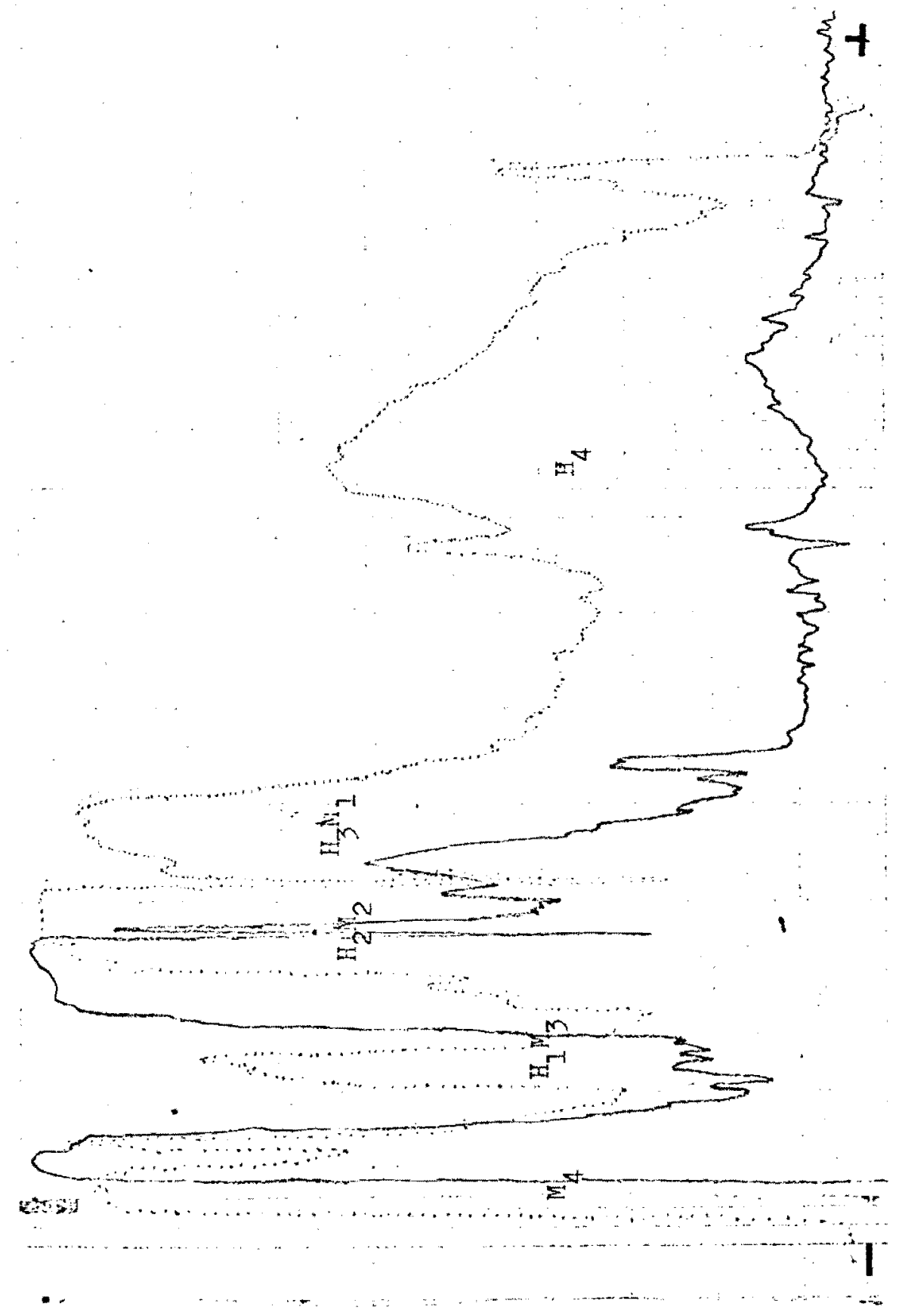

Figure 7. Pattern of $\mathrm{LDH}$ isozyme densitometer tracings of a male Oregon junco. Solid line represents protein stain (Coomassie blue); dotted line represents activity stain (NBT). 


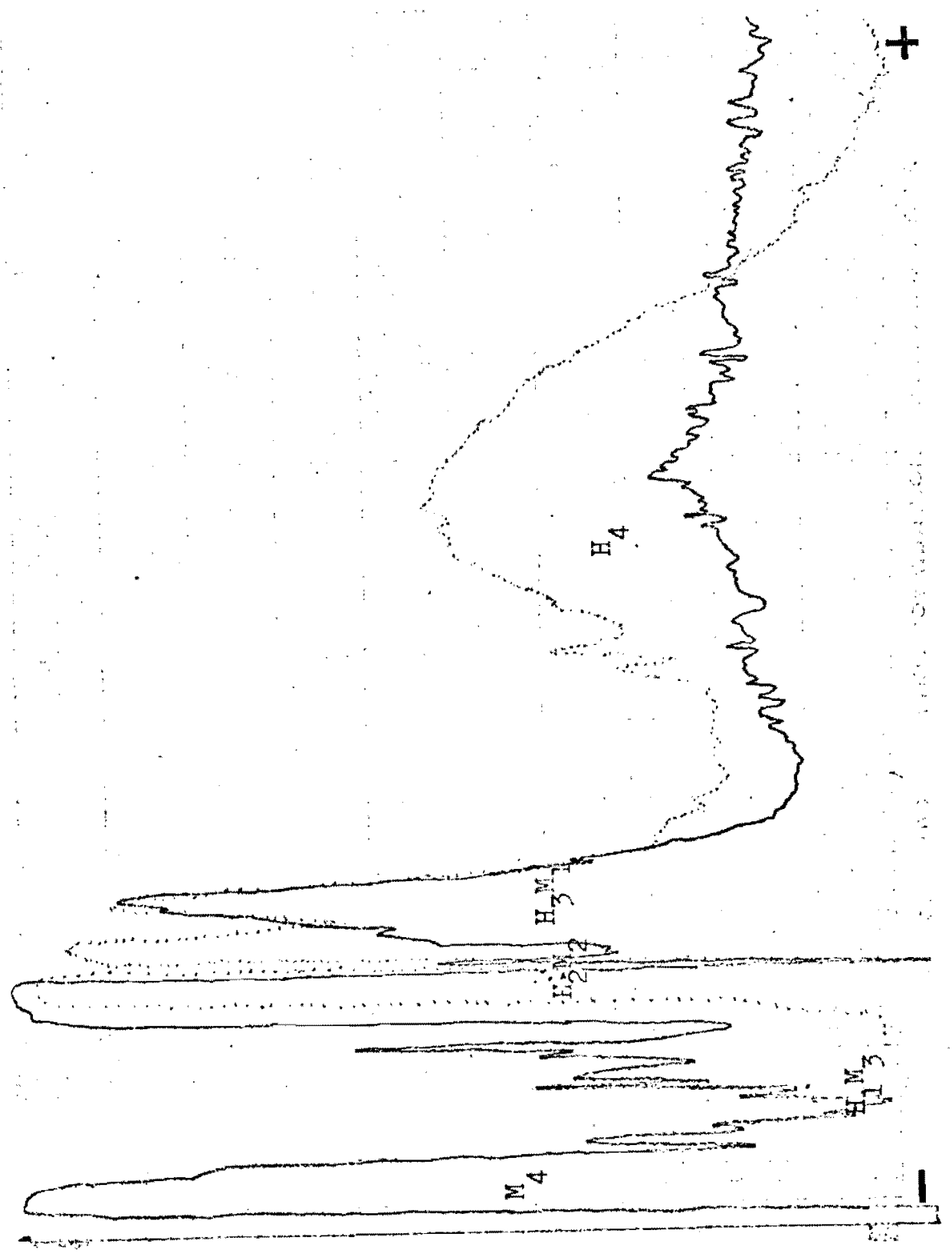

Figure 8. Pattern of LDH isozyme densitometer tracings of a male mufous-sided towhee. Solid line represents protein stain (Coomassie blue); dotted line represents activity stain (NBT). 


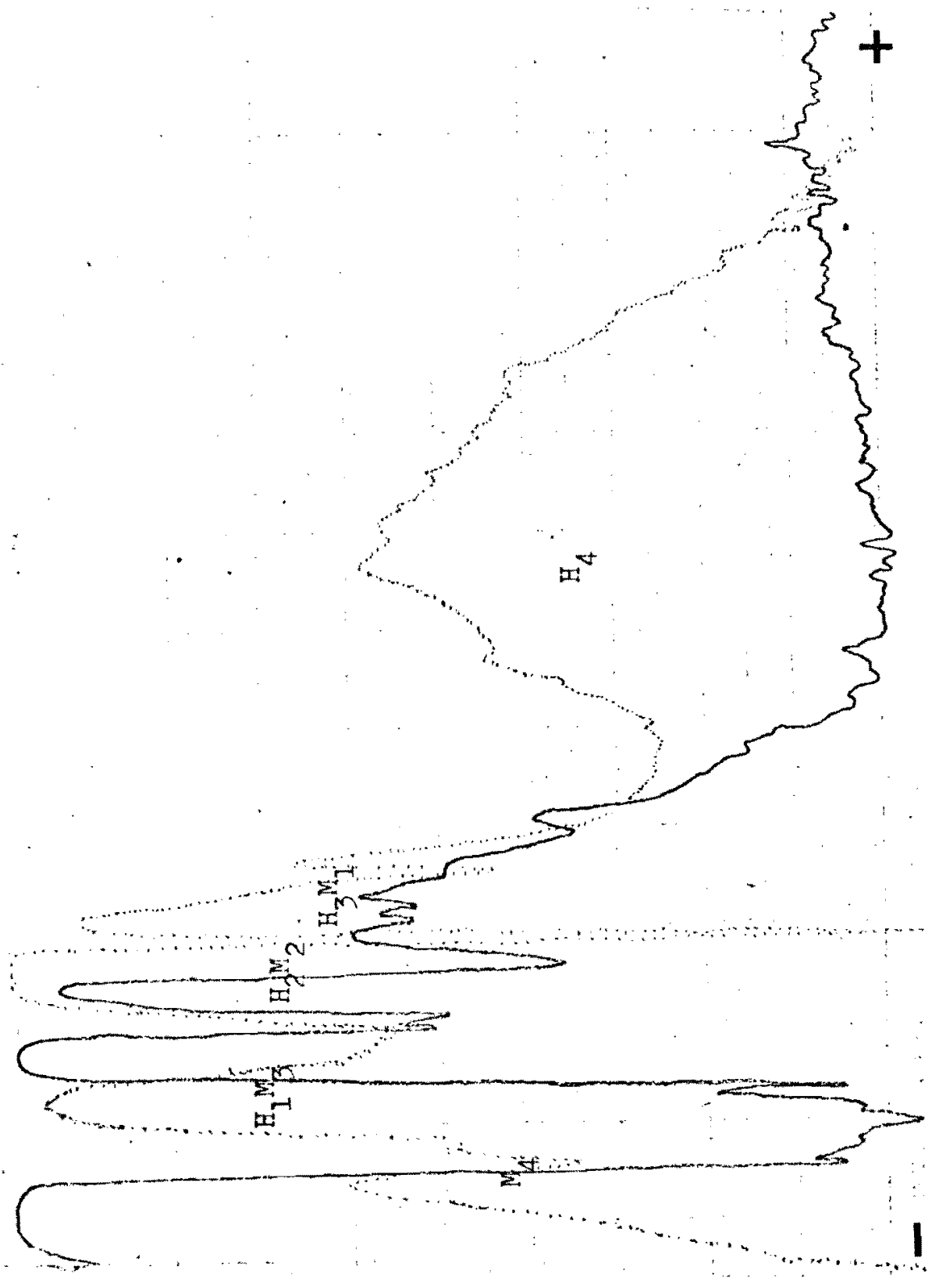

Figure 9. Pattern of $\mathrm{LDH}$ isozyme densitometer tracings of a male white-crom sparrow. Solid line represents protein stain (Coomassie blue); dotted line represents activity stain (NBT). 


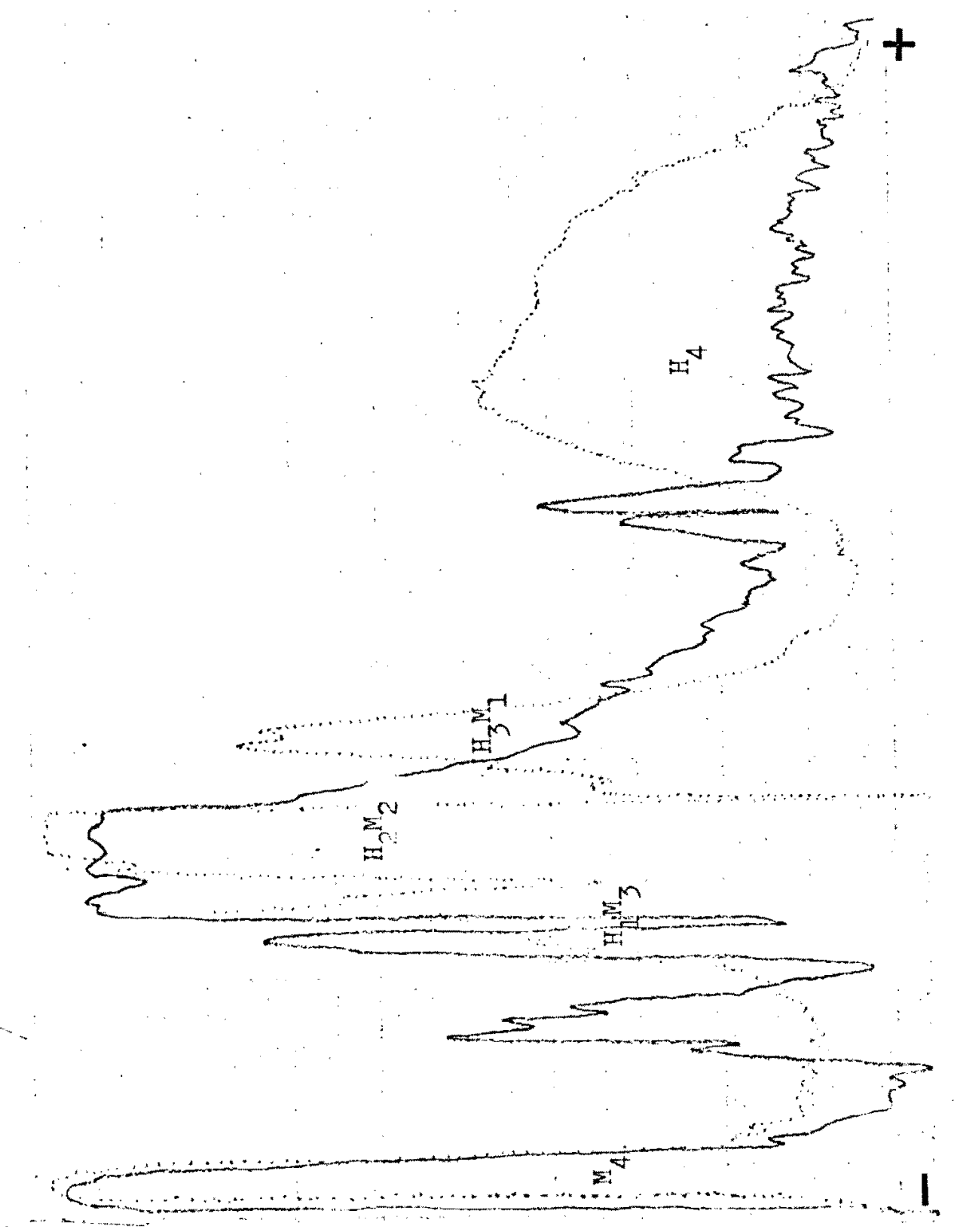

Figure 10. Pattern of LDH isozyme densitometer tracings of a male house finch. Solid line represents protein stain (Coomassie blue); dotted line represents activity stain (NBT). 


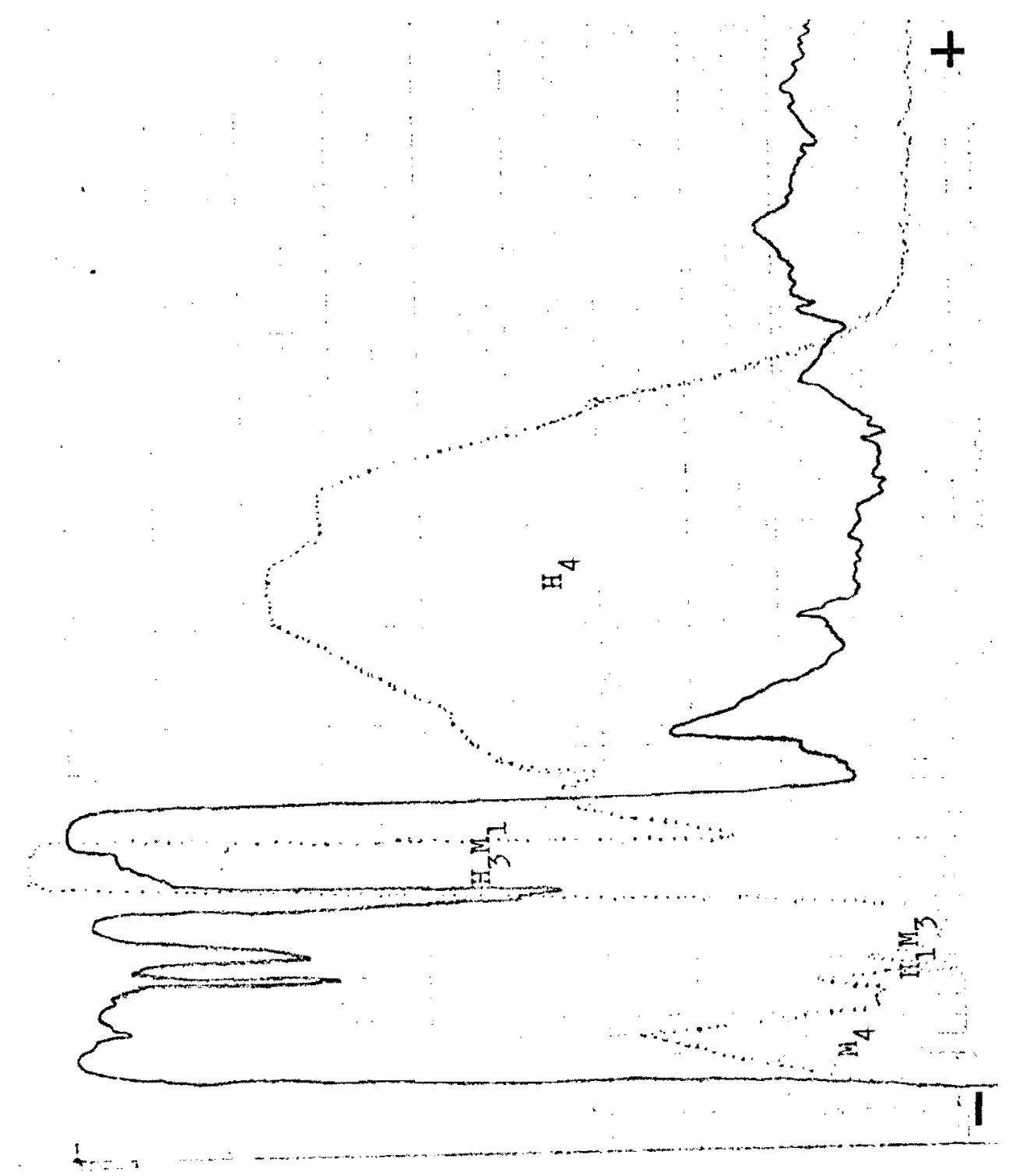

Figure 11. Pattern of IDH isozyme densitometer tracings of a male song sparrow. Solid line represents protein stain (Coomassie blue); dotted line represents activity stain (IBT). 


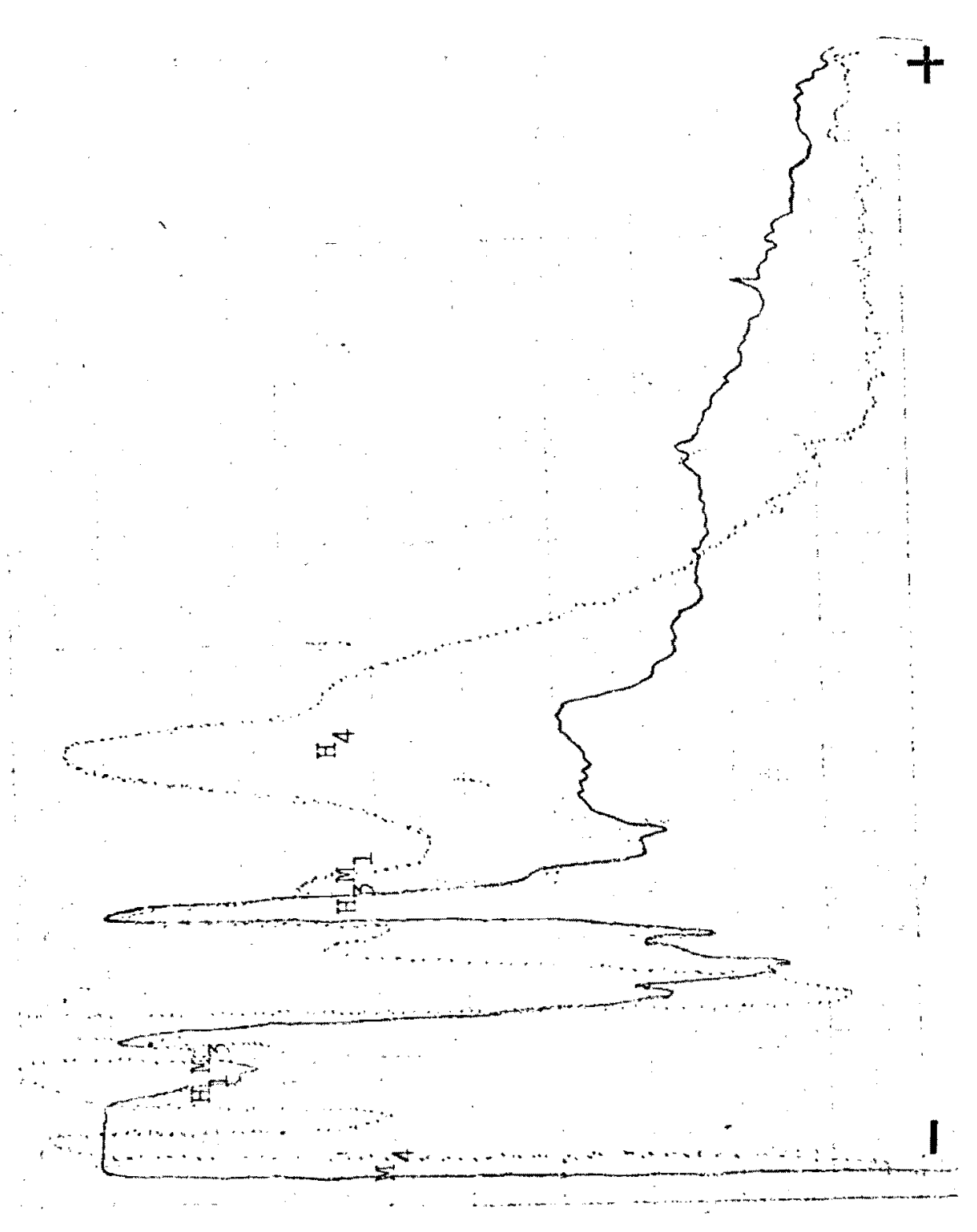

Figure 12. Pattern of $\mathrm{LDH}$ isozyme densitometer tracings of a male fox sparrow. Solid line represents protein stain (Coomassie blue); dotted line represents activity stain (NBT). 


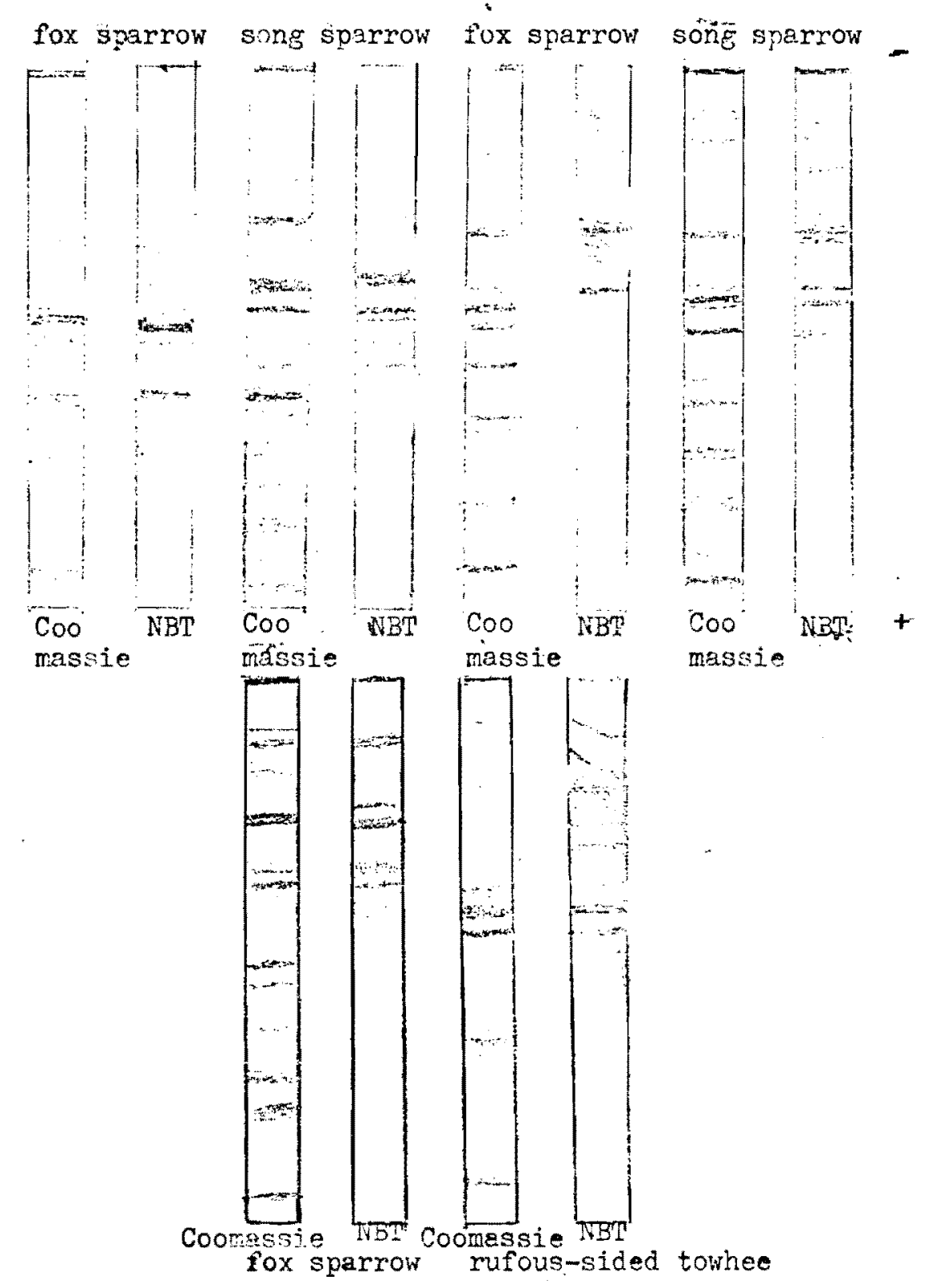

Figure 13: LDH isozyme gel tracings. 


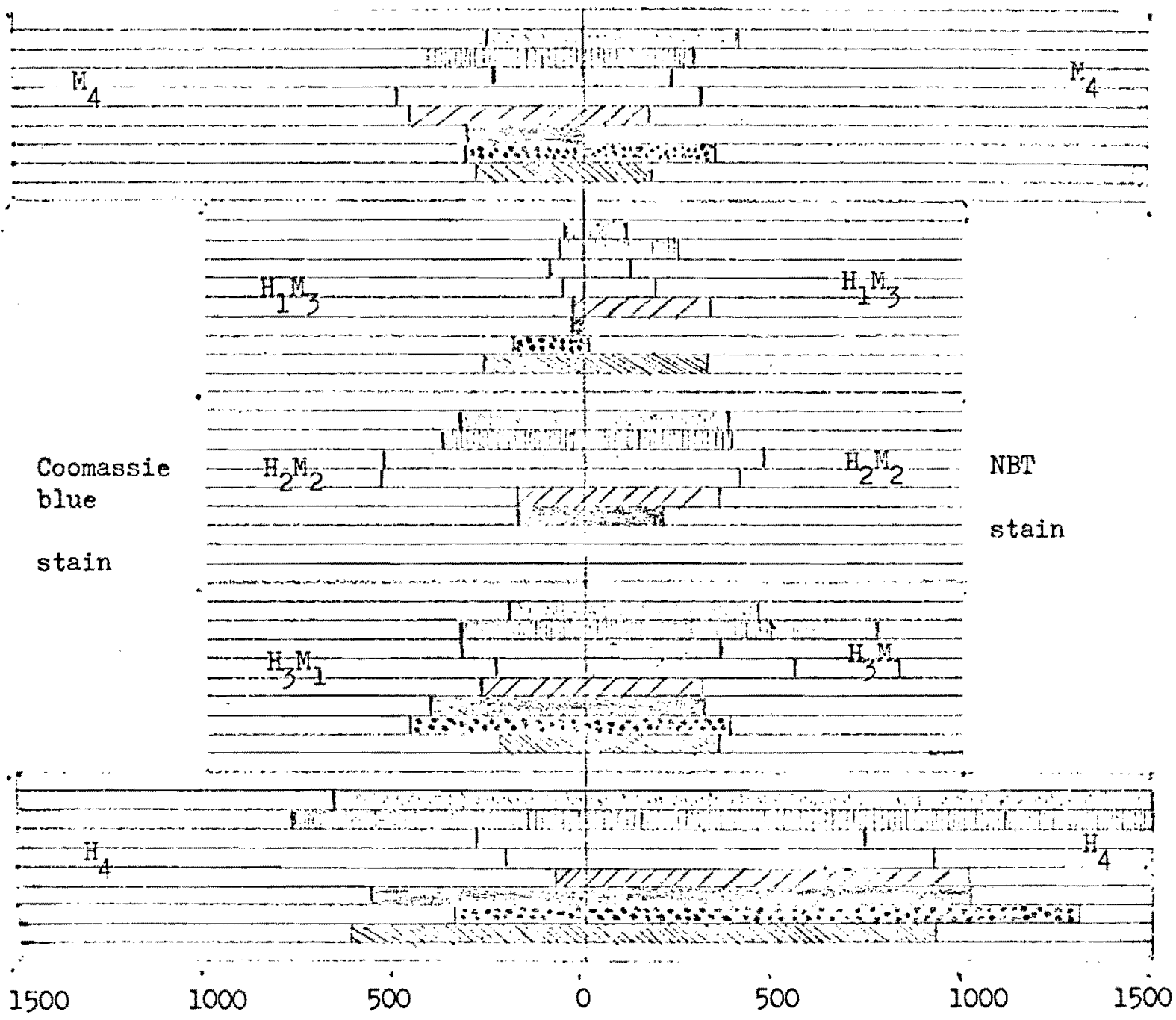

Figure 14. Sumrary of data of eight species of fringilid birds is

the area under the curve of $L D H$ isozyme densitometer tracings. Units used are proportional, $y=$ black-headed grosbeak, $=$ evening grosbeak, $\quad=$ house finch, $(>)=$ oregon junco, white-crown sparrow,,$=$ rufous-sided towhee, $\mathrm{N}, \mathrm{i}=$ for sparrow. 


\section{DISCUSSION}

Four methods of classification for fringillid birds heve been suggested. Beecher (1953) utilized homologies of jaw-structure. Tordoff (1954) employed the structure of homy and bony palates. Nelson (1954) used comparative osteology. St 11cup (1955) relied on leg musculeture and immunological serum analysis. Table II summarizes the classification resulting from these findings. Tordoff, Vison, and Stalloup's methods are discussed at length by Stallcup (1955). Boyden (1942) has suggested that morphologicel features, as opposed to biochemical ones, are nore variable and change faster due to natural selection pressures. Norphological features relate directly to behavior such as feeding habits, as seen in Darwin's study of finches (Sibley, 1957). These finches underwent considerable adaptive radiation from one ancestral stock in a relatively short period of time (Lack, 1939). Newly enercing species can be a problem to the morphoiogical taxonomist due to convergence and parallelism. It was not possible for stallcup (1955) to do every immunological experiment needed to show genetic relationships. If eight species of fringiliid birds were studied, there would be 64 different experiment needed to show all possible relationships.

The evidence from my studies sugiest a classification most like that of Stallcup (1955). He places the fox and song sparrows in the family Carduelidae, subfamily Estrildinae. The evening grosbeak and the black-headed grosbeak were placed in the family Carduelidae, 
subfamily Carduelinae. However, Stallcup (1955) places the juncos and white-crown sparrow in the family Fringillidne, subfamily Richmondeninae and the towhees in the family Fringillidae, subfamily Mmberizinae. Iactic dehydrogenase isozyme patterns suggest that the juncos, white-crown sparrow, and towhees are best assigned to the faruily Cerduelidae, subfamily Richmondininae.

It has been found that enzymes of equal molecular weight can take up different amounts of dye (Hansl, 1964). This might account for the tremendous binding of NBT stain with very little amounts of $\mathrm{H}_{4}$ isozyme. Since $\mathrm{H}_{4}$ isozyme is known to inhibit pryuvate to lactate, any large amount of the enzyme would severely block the metabolic patrway.

The splitting of the five isozymes under conditions given in the results are probably due to partial breakage of the polypeptide chains caused by repented freezing and thawing. Under natural conditions, in which no splitting occurs, the four polypeptide subunits that make up each isozyme will remain a unit. 
TABLE II. Comparison of schene of classification of eight species of fringillid birds.

Here Stallcup: Tordoff: Beecher: Nelson:

Proposed:

\begin{tabular}{|c|c|c|c|c|}
\hline $\begin{array}{l}\text { Family Card- } \\
\text { elidae }\end{array}$ & $\begin{array}{l}\text { Family Cardu- } \\
\text { elidae }\end{array}$ & $\begin{array}{l}\text { Family Plo } \\
\text { ceidae }\end{array}$ & $\begin{array}{l}\text { Family Estr- } \\
\text { ildidae }\end{array}$ & $\begin{array}{l}\text { Family Thr- } \\
\text { aupidae }\end{array}$ \\
\hline $\begin{array}{l}\text { Subf. Est- } \\
\text { rildinae }\end{array}$ & $\begin{array}{l}\text { Subf. Est- } \\
\text { rildinae }\end{array}$ & $\begin{array}{l}\text { Subf. Estril- } \\
\text { dinae }\end{array}$ & $\frac{\text { Carpodacus }}{\text { mexicanus }}$ & $\begin{array}{l}\text { Subf. Rich- } \\
\text { mondeninae }\end{array}$ \\
\hline$\frac{\text { Carpodacus }}{\text { mexicanus }}$ & $\frac{\text { Cerpodacus }}{\text { mexicanus }}$ & $\frac{\text { Ceroodrcus }}{\text { mexicanus }}$ & $\begin{array}{l}\text { Family Thr- } \\
\text { aupidae }\end{array}$ & $\begin{array}{l}\text { Zonotrichia } \\
\text { Ieucophrys }\end{array}$ \\
\hline $\begin{array}{l}\text { Subf. Card- } \\
\text { uelinae }\end{array}$ & $\begin{array}{l}\text { Subf. Cardu- } \\
\text { uelinae }\end{array}$ & $\begin{array}{l}\text { Subf. Cardu- } \\
\text { uelinae }\end{array}$ & $\begin{array}{l}\text { Subf. Pyr- } \\
\text { rhuloxiinae }\end{array}$ & $\frac{\text { Junco }}{\text { oreganus }}$ \\
\hline $\begin{array}{l}\text { Pheucticus } \\
\text { melanocenha- } \\
\text { us }\end{array}$ & $\begin{array}{l}\text { Pheucticus } \\
\text { relenocepha- } \\
\text { us }\end{array}$ & $\begin{array}{l}\text { Pheucticus } \\
\text { melanocepha- } \\
\text { us }\end{array}$ & $\begin{array}{l}\text { Subf. Car- } \\
\text { duelinae }\end{array}$ & $\begin{array}{l}\text { Family Frin- } \\
\text { gillidae }\end{array}$ \\
\hline Hesperiphorna & Hesperiphorna & Hesoerinhorna & $\begin{array}{l}\text { Pheucticus } \\
\text { melanoceoha- }\end{array}$ & $\begin{array}{l}\text { Subf. Ember- } \\
\text { izinae }\end{array}$ \\
\hline yespertina & vespertina & vespertina & us & Pheucticus \\
\hline $\begin{array}{l}\text { Subf. Rich- } \\
\text { mondeninae }\end{array}$ & $\begin{array}{l}\text { Family Frin- } \\
\text { gillidae }\end{array}$ & $\begin{array}{l}\text { Family Frin- } \\
\text { gillidae }\end{array}$ & $\frac{\text { Hesperiphoma }}{\text { vespertina }}$ & $\frac{\text { melanocenha- }}{\text { us }}$ \\
\hline$\frac{\text { Junco }}{\text { oreganus }}$ & $\begin{array}{l}\text { Subf. Fich- } \\
\text { mondeninae }\end{array}$ & $\begin{array}{l}\text { Subf. Rich- } \\
\text { mondeninae }\end{array}$ & $\begin{array}{l}\text { Subf. Thraup- } \\
\text { inae. }\end{array}$ & $\frac{\text { Hesperiohorna }}{\text { vesperina }}$ \\
\hline$\frac{\text { Pipilo }}{\text { erythrowh- }}$ & $\frac{\text { Zonotrichia }}{\text { leuconhrys }}$ & $\frac{\text { Zonotrichia }}{\text { leucophrys }}$ & $\begin{array}{l}\text { Fanily Par- } \\
\text { ulidae }\end{array}$ & \\
\hline$\frac{\text { Zonotrichig }}{\text { leucophrys }}$ & $\begin{array}{l}\text { Junco } \\
\text { oreganus }\end{array}$ & $\begin{array}{l}\text { Junco } \\
\text { oreganus }\end{array}$ & $\begin{array}{l}\text { Subf. Paru- } \\
\text { linae }\end{array}$ & \\
\hline $\begin{array}{l}\text { Family Fring- } \\
\text { illidae }\end{array}$ & $\begin{array}{l}\text { Subf. Thrau- } \\
\text { pinae }\end{array}$ & $\begin{array}{l}\text { Subf. Thrau- } \\
\text { pinae }\end{array}$ & $\frac{\text { Gonotrichia }}{\text { Ieucophrys }}$ & \\
\hline $\begin{array}{l}\text { Subf. Ember- } \\
\text { izinae }\end{array}$ & $\begin{array}{l}\text { Subf. Ember- } \\
\text { izinae }\end{array}$ & $\begin{array}{l}\text { Subf. Frin- } \\
\text { gillidae }\end{array}$ & $\begin{array}{l}\text { Junco } \\
\text { oresanus }\end{array}$ & \\
\hline
\end{tabular}


TABLS II. Cont.

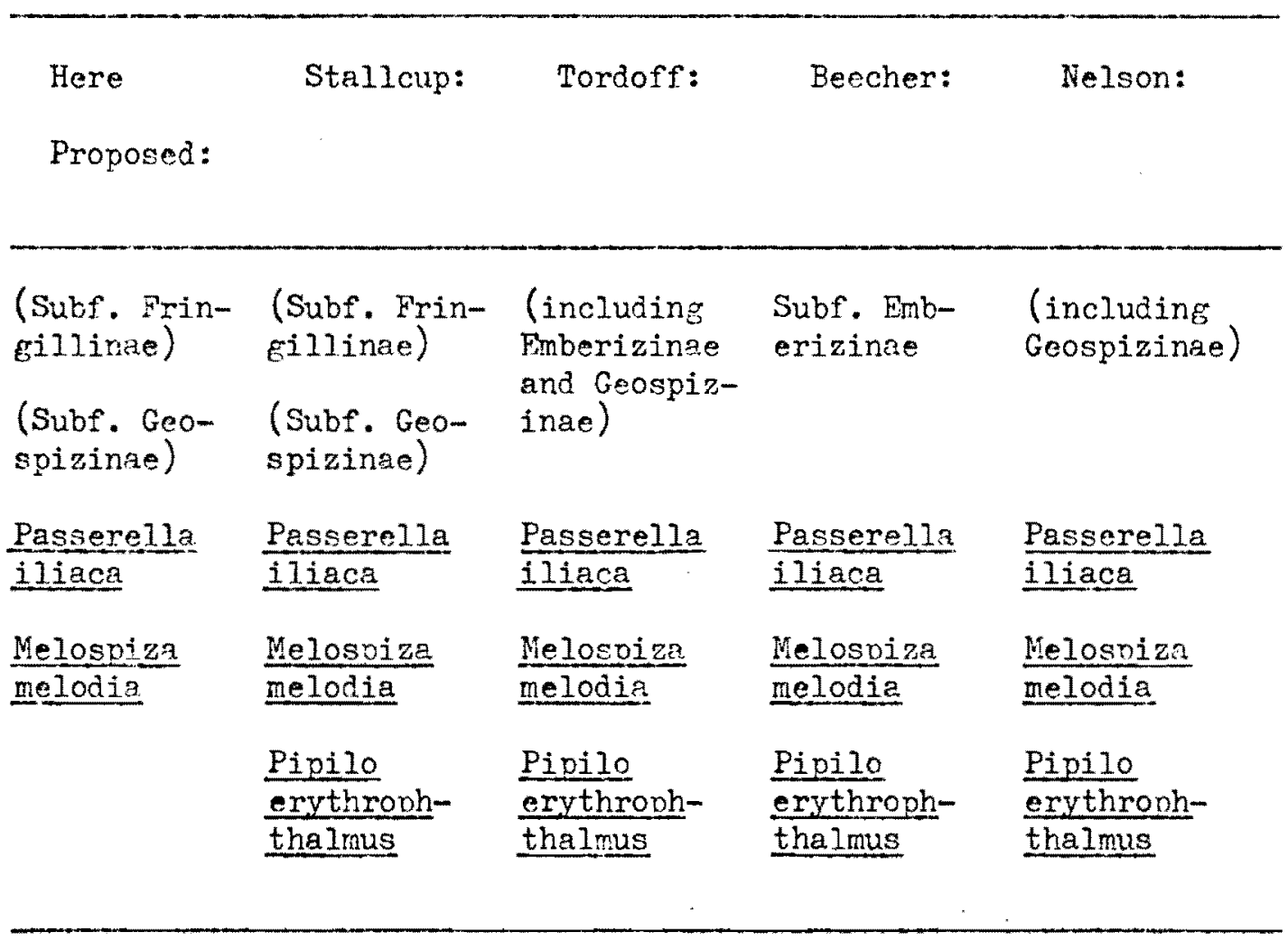




\section{CONCLUSIONS}

If the birds sampled are of the same sex, age, and appear to be healthy, variability within species or subspecies of LDH isozyme patterrs is substantially reduced. A fajr taxonomic comparison can be made if the disc electrophoresis running time, temperature, power supply, concentration of protein and proportion of tissue components are held constant.

My evidence sugesest the following changes in classification from those employed by Stallcup (1955). The mufous-sided towhee should be removed from the family Fringillidae, subfamily Emberizinae, and placed in the family Carduelidae, subfamily Richmondeninae. The Oregon junco and the white-crown sparrow should be removed from the family Fringillidae, subfamily Richmondeninae, and placed in the farily Carduelidae, subfamily Richmondeninae.

If tissue homogenate has been frozen a number of times before electrophoresis and allowed to proceed 120 minutes past the bromphenol tracer, then splitting of $\mathrm{H}_{4}$ and $\mathrm{H}_{3} \mathrm{M}_{1}$ isozymes occurs.

A small amount of $\mathrm{H}_{4}$ isozyme produces a large amount of enzymatic activity. 


\section{BIBLIOGRAPUY}

Bailey, G. S. and Wilson, A. C. (1968), Journal of Biological Chemistry, 243,5843

Beecher, H. J. (1953) Auk, 70, 270.

Boyden, A. (1942), Physiologica]. Zoology, XV, 109.

Chramback, A. and Reisfeld, R. A. (1967), Analytical Biochemistry $20,150$.

Defalco, R. J. (1942), The Biological Bulletin 83, 205.

Fine, I. H. and Costello, L. A. (1962), in Methods of Enzymolory,

New York, Academic Press, p. 958.

Hansl, R. (1964), innals New York Acadeny of Sciences 121, 392.

Johns, J. E. (1963), Bird Banding XXXIV, 209.

Lack, D. (1939) in Darwin's Finches, liew York, Harper, p. 1.

Lehninger, A. I. (1970) in Biochemistry the Molscular Besis of Cell

Structure and Function, ivew York, Worth Pub., p. ${ }^{1}$.

Lewis, W. H. P. (1969), Biochemical Genetics 3, 493.

Lowry, Rosebrough, Fare, Randall (1951), Journal of Biochemistry 93, 265 .

Martin, S. G. (1969), Bird Banding 40, 233.

McCabre, R. A. and Deutsch, H. F. (1952) Auk 69, 1.

Nelson, G. E. (1954), University of Florida pub. no. 9555.

Ornstein, L. and Davis, B. J. (1961), in Distillation Products

Industries, New York. 
Petras, F. G. (1967), Amer. Zool. 7, 704.

31

Sibley, C. G. (1957), Condor 59, 166.

Sibley, C. G. and Johnsgard, P. A. (1959), Condor 61, 85.

Smith, I. (1968) in Chromatographic and Electrophoratic Techninues,

New York, Wiley \& Sons, p.

Stallcup, W. B. (1955), University of Kansas Pub. 157.

Tordoff, H. B. (1954), Nisc. Pub. Wus. Zool. Univ. Mich. 81, 1.

Vese11, E. S. and Brody, I. A. (1964), Annels New York Academy of

Sciences $121,544$. 